\title{
Buddhist Nuns: Between Past and Present
}

\author{
Ann Heirman \\ Chinese Language and Culture, Ghent University \\ Blandijnberg 2, B-9000 Gent, Belgium \\ Ann.Heirman@UGent.be
}

\begin{abstract}
One of the most debated issues in present-day Buddhism is the question of access of women to a full ordination as a nun (bhiksuni $\bar{i})$. Of the three extant ordination traditions - Dharmaguptaka, Theravāda and Mūlasarvāstivāda, it is only in the first one that both men and women are accepted without any dispute as fully ordained members of the monastic community. This situation has given rise to many discussions pleading for a revival of a full ordination ceremony in all Buddhist traditions. In these revival movements, special attention goes to several technical questions of monastic discipline (vinaya). The present article focuses on these questions, while also paying attention to the role played by concepts involving gender. As we will analyze in the first two parts, the technical questions, and the debates surrounding them, are not at all new. Right from the start of the first Buddhist communities, they gradually gained importance. This process thoroughly influenced the spread and the survival of the ordination ceremony for women throughout the history of Buddhism. The third part of our research returns to the present day, demonstrating how the technical questions of the past still play a major role in present-day discussions on status of female monastic members of the Buddhist community.
\end{abstract}

\section{Keywords}

Buddhist nun, vinaya, ordination ceremony

When the Buddha allowed his stepmother Mahāprajāpatī to become a full member of his own monastic order, it marked the start of a twofold community (ubhayasamgha), consisting of both monks (bhiksu) and nuns (bhiksuni $)$. Rules were drawn up for this monastic community, and were eventually gathered in texts, labeled as vinayas (disciplinary texts). As a result of both the geographical spread of the Buddhist 
communities over the Indian subcontinent, and of internal discussions on monastic rules, several vinayas came into being and at a certain point were finalized as separate legal codices that mutually exclude each other. ${ }^{1}$ This separation is certainly the case when ordination procedures are concerned. As $\mathrm{H}$. Bechert puts it: "As a rule, monks belonging to different Nikāyas [schools] do not conduct joint Sanghakarmas [formal acts]. Though they may not always dispute the validity of each other's ordination, they do not recognize it as beyond dispute either. If there were doubts about the validity, the Sanghakarman would be questionable. If the validity of ordinations is called into question, the legitimation of the Sangha is endangered" (Bechert 1993:54). Although it is unsure at what time exactly the several vinayas started to operate as separate legal codices, it is clear that when the Chinese vinaya translations were made, starting from the third-fourth century C.E., the differences between the several vinayas were acknowledged by Indian and Chinese masters alike. ${ }^{2}$

While more vinaya traditions have existed, the texts of six traditions are extant, one in Pāli — the Theravāda tradition, and five in a Chinese translation. ${ }^{3}$ The first four of these have been translated in the fifth century. In chronological order these are the Shisong lü十誦律 (T. 1435), Sarvästivädavinaya; the Sifen lü 四分律 (T. 1428), Dharmaguptakavinaya; the Mohesengqi lü 摩訶僧祇律 (T. 1425), Mahäsämghikavinaya; and the Mishasai bu hexi wufen lü 彌沙塞部 和酸五分律 (T. 1421), Mahiśásakavinaya. Later, in the beginning of the eighth century, the monk Yijing 義淨 translated large parts of the Mülasarvāstivādavinaya (Genbenshuoyiqieyou bu pinaiye 根 本 說一 切有部毘奈耶, T. 1442-1451), as well as other vinaya texts belonging to the same school. Of the Mülasarvästivädavinaya, a Tibetan

1) See, among others, Bechert 1982:67-68 and 1993:54; von Hinüber 1999:89-91; Heirman 1999.

2) See Heirman, 2007.

3) Although at the end of the fifth century a Päli vinaya was translated into Chinese, the translation was never presented to the emperor and was subsequently lost (see Heirman, 2007:190-192). Besides the Pali vinaya, a second text to have survived in an Indian language only is the chapter for nuns (bhikșuñivibhañga) of the MahāsāṃghikaLokottaravādins, preserved in a transitional language between Prākrit and Sanskrit (Roth 1970:lv-lvi). A full Mahāsāṃghika-Lokottaravāda vinaya is not extant. 
translation and many Sanskrit fragments are extant. ${ }^{4}$ Not all of the extant vinaya texts, however, are still actively used in full ordination ceremonies. Only three traditions have been continued: the Dharmaguptaka tradition mainly followed in China, Taiwan, Vietnam and Korea, ${ }^{5}$ the Mūlasarvāstivāda tradition based in Tibet, and the Southeast Asian Pāli Theravāda tradition. For nuns, the situation is different, since only in the Dharmaguptaka tradition is a full ordination as a nun still possible. ${ }^{6}$

Today, in many parts of the world, Buddhist groups try to revive a full ordination procedure for women in the two traditions only active for men. This ordination procedure involves several technical vinaya questions, all linked to the fact that in order to be legally valid, a full ordination ceremony has to be carried out in the presence of an adequate quorum of fully ordained witnesses, in principle coming from the same tradition. The present article focuses on these technical questions, while also paying attention to the role played by concepts involving gender. In the next two parts, we analyze how technical questions continuously gained importance, and what consequences this process involved for the spread and the survival of the ordination ceremony for women. The last part of our research demonstrates how the same technical questions still play a major role in present-day discussions on the revival of a full ordination for women.

\section{Basic rules: Founding of the First Nunneries}

According to tradition, the first nun ever to have been ordained was the Buddha's stepmother, Mahāprajāpatī. Her story appears in most vinayas, as well as in some other early Buddhist texts. ${ }^{7}$ Although Mahāprajāpatī is accordingly seen as the first Buddhist nun, it is very likely that the

\footnotetext{
4) For details, see Yuyama 1979:12-33.

5) In Japan full vinaya ordinations for women had already disappeared in the eighth century (Meeks 2006:53, 60-61).

6) As we will see further, a few ordinations have recently been carried out in the Păli tradition. The validity of these ordinations is still under discussion.

7) For a comparison of these texts, see Heirman 2001:278-284. For a comparison of the story as found in the Pāli Vinaya and the one of a Sanskrit vinaya text belonging to the Mūlasarvāstivāda School, see Sponberg 1992:13-18; Hüsken 1993:151-165.
} 
story of her ordination arose when the community of nuns already existed for some time. ${ }^{8}$ Still, her entrance in the Buddhist monastic order (samgha) and her acceptance of the first basic rules for a female monastic community constitute the point of reference for the development of the first Buddhist nunneries. At first, the story goes, Mahāprajāpatī was denied full ordination as a nun by the Buddha, although he later answered affirmatively to the monk Ānanda's question whether or not women can become arhats and thus obtain enlightenment. In many accounts, the fact that Mahāprajāpatī was the Buddha’s stepmother also played a significant role, and extensive reference is made to the debt the Buddha is said to owe to his mother for everything she has done on his behalf.' Through further mediation of Annanda, the Buddha then allows women to enter the Buddhist monastic order, providing that they accept eight fundamental rules (gurudharma) which will make the nuns' order (bhiksunisamgha) dependent upon the hierarchically superior monks' order (bhiksusamgha). Although tradition holds these rules to have been given by the Buddha at the occasion of Mahāprajāpatî̀s acceptance into the order, the work of many researchers has shown that they were in all likelihood formulated after the order of nuns had already developed for some time. ${ }^{10}$ In most vinayas, the rules differ only slightly. Below they are enumerated following the present-day active vinaya for nuns, the Dharmaguptakavinaya (T. 1428:923a26-b21).

1) Even when a nun has been ordained for one hundred years, she must rise up from her seat when seeing a newly ordained monk, and she must pay obeisance.

2) A nun may not revile a monk saying that he has done something wrong.

\footnotetext{
8) See, among others, Horner 1930:102-103; Sponberg 1992:32, note 14; Harvey 2000:383-391; Williams 2000; Chung 2006:12-14.

9) These aspects of Mahāprajāpatîs story have been researched in detail by Ohnuma (2006). As shown by Ohnuma (2006:871), the 'debt to the mother' needed to be repaid, and this repayment was often explicitly linked to the establishment of a nuns' order. 10) For a discussion and a comparison, see, among others, Horner 1930:118-161; Nolot 1991:397-405; Hüsken 1993:154-164; Heirman 1997:34-43; Hüsken 1997:345-360; Heirman 1998; Heirman 2002a, Part I:63-65; Chung 2006.
} 
3) A nun may not punish a monk, nor admonish him, whereas a monk may admonish a nun.

4) After a woman has been trained as a probationer (siksamānā) for two years, the ordination ceremony must be carried out in both orders (i.e. first in the nuns' order, and then in the monks' order).

5) When a nun has committed a samghāvaśeșa offense (an offense that leads to a temporary exclusion), she has to undergo the penance in both orders.

6) Every fortnight, nuns have to ask monks for instruction.

7) Nuns cannot spend the summer retreat (rainy season) in a place where there are no monks.

8) At the end of the summer retreat, nuns have to carry out the pravāraña ceremony ${ }^{11}$ (also) in the monks' order.

The story shows women as soteriologically equal to men, but institutionally inferior. ${ }^{12}$ It also enumerates several reasons why this inferior position, formalized through the eight gurudharmas, is necessary for the survival and continuation of the Buddhist order. ${ }^{13}$ Women weaken the community, and thus the doctrine, by making it less respected. This danger can only be countered if the monks strictly control the nuns' community. The Dharmaguptakavinaya (T. 1428:923b19-20) also adds a more positive note: monks not only fight the danger of a less respected community by supervising the nuns' order, but they also offer nuns a way to get across the dangers of the world.

According to tradition, Mahāprajāpatī did not go alone to see the Buddha. She was accompanied by numerous women of her own clan, the Saakyas. While for Mahāprajāpatī the acceptance of the eight fundamental rules is seen as her ordination, this is not automatically the case for the Śākya women. On this point, the vinaya texts differ. The Pāli Vinaya (Vin II:256-257) and the Mahisáasakavinaya (T. 1421:186a28b3) state that the women should be ordained by a chapter of monks.

11) The pravāranā (or invitation) ceremony is held at the end of the summer retreat. On this occasion, every monk (and nun) is expected to invite his (her) fellow-monks (nuns) to point out his (her) wrongs, if any, whether seen, or heard, or suspected.

12) For a detailed analysis, see Sponberg 1992.

13) For details, see Heirman 2001:278-284. 
The Dharmaguptakavinaya (T. 1428:923c8-9 and 926a27-b3) sees it differently and considers the acceptance of the eight fundamental rules as a valid ordination for both Mahāprajāpatī and the Śākya women. ${ }^{14}$ The same idea is also put forward by the Mülasarvastivādavinaya (T. 1451:351c1-27).

Throughout the history of Buddhism, the story of Mahāprajāpatī has been interpreted over and over again. In some texts, such as the Chinese Dáaidao biqiuni jing (T. 1478, 大愛道比丘尼經, Sütra on the Bhiksuni Mahäprajāpatī), a later vinaya text, it takes a misogynistic turn. ${ }^{15}$ Women are no longer seen as a threat to the community because they make it socially less respected, but are now considered to be an inevitable threat to the goals of Buddhist men personally. Femininity itself is the cause of failure. ${ }^{16}$ This misogynic view on women is not unique to the story of Mahāprajāpatī. It can be found quite frequently in narrative literature, especially in literature from the fourth century of the Common Era on, as described in detail by L. Wilson (1996) in Charming Cadavers, Horrific Figurations of the Feminine in Indian Buddhist Hagiographic Literature. However, this rather negative view is not the only way in which Buddhist literature discusses the feminine. Stories about wise women or stories focusing on the irrelevance of gender distinction

14) This also seems to be the viewpoint of the Sarvāstivāda commentary Sapoduobu pini modeleqie 薩婆多部毘尼摩得勒伽 (translated by Samghavarman in 435, cf. Yuyama 1979:8), T. 1441:594a22-23 and 594b3: Mahāprajāpatī and others, presumably the Sākya women, receive the ordination by accepting the eight rules. For more details, see Heirman 2001:278-284, 290-291.

15) It is uncertain when and by whom the text has been translated into Chinese, but it was extant in the first half of the fifth century. Moreover, although the text has been classified as a translation by the earliest catalogues, it cannot be totally excluded that it is a Chinese compilation. (For details, see Heirman 2001:284-285.)

16) See for instance T. 1478: "if one has received a female shape, one is bound to lust and one cannot constrain oneself" (951b14-15); or "women impede themselves (on the way to liberation)" (952c24-25); or "women cannot straighten their mind, how could they straighten the mind of other people; women cannot save themselves, how could they save other people; women live in sin, how could they free other people" (953c10-12). Since in T. 1478, Mahāprajāpatī is accompanied by five hundred "mothers," a fact which seems to put stronger emphasis on motherhood than earlier accounts (in which Mahāprajāpatī is followed by "women”), Ohnuma (2006:884-885) suggests that T. 1478 might also include a discomfort and a hostility towards the "debt to the mother" theme. 
are widespread. ${ }^{17}$ Moreover, one should make a differentiation between images of narrative literature and the reality of daily life of Buddhist nuns. In fact, as shown by G. Schopen (1997:72-85), all members of the monastic community, including monks, nuns and probationers, are frequently represented by early Buddhist texts as fairly wealthy people, without any anti-female connotation. This is still more obvious from the many Indian donative inscriptions of the first centuries C.E., that frequently name individual members of the monastic community, monks and nuns, as donors. From the fifth century on, however, nuns are less represented. ${ }^{18}$ When the Chinese monk Yijing travels to India in the late seventh century, and tells his readers about the monastic community at Nālandā, his account does not contain any misogynistic view, but he does refer to the precarious economic situation of nunneries, due to the low amount of donations given to Buddhist nuns (T. 2125:216b11-24).

The above again shows us that distinction has to be made between the several narrative genres, and between narration and the relevant historic context. Technical questions, such as the vinaya rules on the position of women within the Buddhist samgha, are on the one hand influenced by gender related concepts, but are on the other hand not an exact mirror of the various views of the female as found in the many narrative genres. While the perspective on women changes widely according to time and region, the basic rules laid down in the vinaya remain the same. Changes are perceptible only in the way one deals with these rules. In the next part of our research, we will therefore focus on the interpretation of the institutional vinaya rules, and more particularly, on the story of Mahāprajāpatī and the eight fundamental rules, in the different contexts that Buddhism encounters through time and space.

\section{Spread of Buddhist Monasticism}

Throughout the spread of Buddhist monasticism, the vinaya rules on ordination, as well as the story of Mahāprajāpatī and her acceptance of

17) Cf. Harvey, 2000:368-379.

18) Schopen 1997:238-257; 2004:329-330. See also Harvey 2000:392-393. 
the eight fundamental rules, remain central themes in the discussion on the position of women within the Buddhist samgha. When Mahāprajāpatī accepted the gurudharmas, she also agreed that once a nuns' order had been established, the only way to receive an ordination was through an ordination ceremony in both orders (first in the nuns' order and second in the monks' order) by means of a jnapticaturtha karman - a formal act consisting of one motion and three propositions that concern the acceptance of the motion by the assembly of monks or nuns, and followed by a conclusion. ${ }^{19}$ This obligation is never to be transgressed. It assures the proper and uninterrupted transmission of the rules for women from the time of the Buddha onward. ${ }^{20}$

Permission for the extension of the case of Mahāprajāpatī, or of the ordination of the Sākya women, to new communities of women eager to become nuns is not found in the vinayas or in early vinaya commentaries. ${ }^{21}$ The Sarvāstivādavinaya even explicitly says that only one person could ever be ordained as Mahāprajāpatī (T. 1435:410a23). This statement is repeated in a commentary on the Sarvastivädavinaya, the Sapoduo pini piposha (薩婆多毘尼毘婆沙), T. 1440:511b3-4. ${ }^{22}$ Another commentary on the Sarvastivädavinaya, the Sapoduobu pini modeleqie (薩婆多部昆尼摩得勒伽), ${ }^{23}$ T. 1441:594b8, says that after the ordination by means of a jnapticaturtha karman had been set up, an ordination based on the acceptance of the eight fundamental rules was no longer possible. It was this opinion that was followed when Buddhism spread from the north of India to other regions. As further indicated by all vinayas, an ordination ceremony based upon a jnapticaturtha karman is valid only when carried out in the presence of a minimum quorum of monks and nuns. To ordain a female candidate, most vinayas state that a minimum of ten nun witnesses is required for the first ceremony in the nuns' order, and a minimum of ten monks for the second ceremony in the monks' order. In border regions, five nuns

\footnotetext{
19) For details on this ceremony, see Heirman 1997; 2002a, I:75-79.

20) The survival of a community relies on an uninterrupted ordination tradition. (See for instance, Bechert 1961:45; Kieffer-Pülz 1992:28; Harvey 2001:71).

21) See also Hüsken 1997:364-365; Heirman 2001:289-291.

22) The Sapoduo pini piposha was probably translated after the translation of the Sarvāstivādavinaya and before 431 (Yuyama 1979:8-9).

23) See note 14.
} 
and five monks can presumably carry out the ordination. ${ }^{24}$ The latter rules also include a potential danger: in the case that witnesses are no longer available, an ordination based on a dual ceremony (first in the nuns' order and then in the monks' order) carried out by means of a jnapticaturtha karman is no longer possible, and a community inevitably dies out. This is exactly what happened to the nunneries in the Theravāda and Mūlasarvāstivāda traditions. As we will see in the following, only the Dharmaguptaka tradition managed to escape the same fate.

\section{Theravāda and Mülasarvāstivāda Traditions}

According to the Dipavamsa and the Mahävamsa, two Sinhalese chronicles of respectively the fourth and the sixth centuries, the nuns' order has been introduced in Sri Lanka by Sanghamittā, the daughter of king Aśoka (reigned 268-233 в.C.E.) and the brother of Mahinda. ${ }^{25}$ Mahin$\mathrm{da}$ is said to have gone to Sri Lanka with an adequate quorum of monks in order to initiate a monastic order for men. Buddhism at once received a friendly welcome on the island, and, according to legend, even queen Anulā and her retinue wanted to enter the Buddhist samgha. The story further relates that Mahinda explained to the women that only nuns who are fully ordained can legally perform the ceremony of going forth (Pāli pabbajā, Skt. pravrajyā) for women. ${ }^{26} \mathrm{He}$ therefore invited his sister Sanghamittā to Sri Lanka, and she accordingly made the long journey together with eleven other nuns. ${ }^{27}$ This enabled the establishment

\footnotetext{
24) Pāli Vinaya, Vin II:271-274; Mahīśāsakavinaya, T. 1421:187c7-8; Mahāsāṃghikavinaya, T. 1425:473c24-26; Dharmaguptakavinaya, T. 1428:763b24, 763c28-29, 925a27ff., 926a20; Sarvāstivādavinaya, T. 1435:331a18-19ff., 331b16-17, 332c2829ff., 333a15-16, a29-b1, 8-9, 17. For a detailed analysis, see Heirman 2001:294-295. The Mūlasarvāstivāda tradition requires twelve nuns and ten monks in a central region (T. 1453:462c1-3; Schmidt 1993:256; for details, see also Chung 2006:11-12).

25) Oldenberg 1879:84-85, 88 (16.74-95; 16.38-39), translation 191-192, 195; Dipavamsa 62-113, translation 167-22; Geiger 1958:112, 141, 155 (15.19-23; 18.9-11; 19.65); translation Geiger 1912:98, 122-123, 133.

26) Before entering the order as a fully ordained monk (bhiksu) or nun (bhikșnīi) one first has to go forth and become a novice (śrämanera, f. śämanerī; see Heirman 2002a, I:66).

27) Geiger 1958:148 (19.5); translation Geiger 1912:128.
} 
of a nuns' order in accordance with the vinaya rules. ${ }^{28}$ From Sri Lanka, the ordination spread to other parts of Southeast Asia, particularly to Burma. ${ }^{29}$ Although it was at times very successful, the nuns' order eventually died out. The last reference to Theravāda nuns is found in Burma in the thirteenth century. In Sri Lanka, the ordination probably died out in the eleventh century. ${ }^{30}$ Only in the late nineteenth century, some women again organized themselves in monastic communities, without, however, having access to a full bhiksuni $\bar{\imath}$ ordination. ${ }^{31}$

In Tibet, the monastic community follows the Mülasarvästivädavinaya. Although the Mūlasarvāstivāda tradition certainly also ordained nuns, there seems to be no tangible proof that this full ordination for women has ever been introduced in Tibet. The highest ordination women can receive is the one of novices (Harvey 2000:399; Gutschow 2004:168197). Still, it cannot be excluded that at some time in the past exceptional women may have received full ordination by monks alone (Guschow 2000:108; Harvey 2000:399).

\section{Dharmaguptaka Tradition}

The Dharmaguptuka tradition is seemingly the only one in which a full ordination for women has been continued until today. It is the ordination tradition followed by nuns from China, Taiwan, Vietnam and Korea. When the first ordination of women took place in China in the beginning of the fourth century, the ceremony was carried out in the presence of monks only, since nun witnesses were at that time not available in China (Heirman 2007:172-174). However, later nuns

28) For more details, see among others, Bartholomeusz 1992:37-41; [1994] 1996: $17-23$.

29) It is doubtful whether a full ordination for women has ever been established in Thailand, Laos or Cambodia (Harvey 2000:395).

30) See, among others, Gunawardana 1988:33, 37-39; Harvey 1990:222; Bartholomeusz 1992:39-40; Harvey 2000:395; De Silva 2004:119-120; Bartholomeusz [1994] 1996:21; Kawanami 2007:229-230.

31) For a study of this movement, see, for instance, Bartholomeusz [1994] 1996. For later Theravāda movements, see among others, Kawanami 1990 (Burma); Harvey 2000:395-398; Salgado 2004 (Sri Lanka); LeVine and Gellner 2004:171-206 (Nepal), Seeger 2006-2008 (Thailand); Mrozik 2009. 
were anxious to have been ordained on a correct legal basis, that is in accordance with the vinaya texts. The discussion reached its peak in the first half of the fifth century and eventually led to a new ordination ceremony ca. 433 whereby Chinese nuns were offered a second ordination, this time in the presence of an adequate quorum of fully ordained nuns who had come from Sri Lanka. ${ }^{32}$ An important source for the discussions on nuns in the first centuries of Chinese Buddhism, is the Biqiuni zhuan 比丘尼傳 (Biographies of Bhiksunis), a collection of biographies of Buddhist nuns from the fourth to the early sixth century. ${ }^{33}$ It shows us that the Buddhist masters eventually opted for a strict interpretation of the vinaya rules saying that an ordination needs to be performed by means of a jnapticaturtha karman in the presence of an adequate number of both nuns and monks. ${ }^{34}$ This issue was undoubtedly the focus of the debate on the validity of the nuns' ordination in fifth century China. ${ }^{35}$ Remarks spread over the biographies show that one also tried to stay in line with several other vinaya rules on ordination, such as the establishment of an ordination platform (T. 2063:939c23), ${ }^{36}$ or the fact that a woman candidate must be of sufficient age (T. 2063:941a22-b1), ${ }^{37}$ most probably twenty years as stipulated in all vinayas. ${ }^{38}$ There is also a brief hint to a probationary period of two years that has to precede the full ordination ceremony (T. 2063:937b28-29). This is in accordance with one of the eight fundamental rules as accepted by Mahāprajāpatī. However, there is

32) For a discussion, see Heirman 2001:289-298.

33) T. 2063, said to have been compiled by Baochang 寶唱 between 516 and 519 (for a discussion on Baochang's role, see Georgieva 2000:16-21; De Rauw 2005). The Biqiuni zhuan has been translated by Tsai 1994. For a study of the nuns of the Biqiuni zhuan, see Georgieva 2000:84-226.

34) T. 2063:937c1-3 and 939c21-22. For more details, see Heirman 2001:293-298.

35) As discussed by Heirman 2010:65-69, later Chinese vinaya masters such as Daoxuan 道宣 (596-667) and Dajue 大覺 (first half of the eighth century), continue to focus on the importance of a legally valid dual ordination.

36) Heirman 2001:294. For details on the role of the ordination platform, see KiefferPülz 1992:27-28, 192-194.

37) See also Gaoseng zhuan 高僧傳 (Biographies of Eminent Monks, compiled by Huijiao 慧皎 ca. 530, cf. Wright 1954:400), T. 2059:341b3-4.

38) On the age of a candidate, see, among others, Heirman 2002a I:82-88; KiefferPülz 2005. 
no proof that such a probationary period has ever been effectively introduced in China. ${ }^{39}$ The lack of it has recently even led to some discussion about the nuns' ordination line between one of the leading Taiwanese nuns, Shih Chao-hui 釋昭 慧 ${ }^{40}$ and the Dalai Lama as the main representative of the Tibetan masters. ${ }^{41}$

Apart from the technical guidelines that receive attention in the Biqiuni zhuan, it is also highly interesting to have a look at what is not taken into account by the early Chinese masters. In this context, it is striking that no attention whatsoever went to recording which vinaya text was used at the second ordination ceremony. The result is that one cannot know exactly which tradition was begun at this crucial event. In the middle of the fifth century, three main vinaya traditions were active in China: in the south the Sarvasstivaddavinaya, and in the north the Mahäsämghikavinaya, and to a lesser extent the Dharmaguptakavinaya (Heirman 2002b:400-423). Since the ordination ceremony took place in the present city of Nanjing, in the south of China, the Sarvästivādavinaya might have been used. On the other hand, the nun witnesses all came from Sri Lanka and in all likelihood were ordained in the Pāli Theravāda vinaya tradition. Despite a potential discussion on which vinaya tradition to use as a basic reference point for the ceremony, the matter does not seem to have been an issue for the Chinese masters. ${ }^{42}$ Still, all vinayas known to the Chinese in the fifth century state that a legal procedure (karman) has to be carried out by a harmonious samgha (samagra samgha) ${ }^{43}$ which implies that there has to be unity (among all participants) as for the recitation of the prätimokș (list of precepts) at the posadha ceremony. ${ }^{44}$ This kind of recitation is only possible within one and the same vinaya tradition. On the other hand, it is certainly

\footnotetext{
39) See Heirman 2008a:124-133.

40) Shih Chao-hui 2000. On Shih Chao-hui, and especially on her protest against the eight fundamental rules, see Li 2000a:154-161; Bingenheimer 2004:131-142.

41) See Heirman 2008a:108-109.

42) On the eclectic use of vinaya texts in the first centuries of Chinese Buddhism, see Heirman, 2007:192-195.

43) Pāli Vinaya, Vin I:316; Mahísásakavinaya, T. 1421:161c17; Mahāsāmghikavinaya, T. 1425:422b9-14; Dharmaguptakavinaya, T. 1428:885c14-15; Sarvāstivādavinaya, T. 1435:220a13-14, c3-5.

44) The posadha ceremony is a ceremony held every fortnight. On that occasion, the prātimoksa (list of precepts) is recited. Every vinaya tradition has its own, somewhat
} 
not to be excluded that the Sinhalese nuns did participate in posadha ceremonies conducted in Chinese and did recite the same prätimoksa as the Chinese women did, and this before the actual ordination ceremony eventually took place. In the biography of the monk Gunavarman who played a central role in the discussion on the ordination for women, we read that he asked the Sinhalese nuns to study Chinese (Gaoseng zhuan, T. 2059:341b6). This hints that it might have been important to the Buddhist masters that the Sinhalese witnesses and the Chinese participants all recite the same texts in the same language.

In any case, since more than one vinaya was active in fifth century China, it seems impossible to say which vinaya tradition was used at the second ordination ceremony for nuns. Only at the beginning of the eighth century, one vinaya tradition - the Dharmaguptaka tradition eventually imposed itself, supported by an edict issued by the Chinese emperor. ${ }^{45}$ From that time on only one vinaya tradition was followed in China. From China, it spread to other East Asian regions.

\section{The Revival Movement}

Today, the position of women, and more particularly of nuns, in the Buddhist samgha is again one of the major issues discussed in Buddhist communities. As noted above, a full ordination for women is only preserved through the Chinese Dharmaguptaka ordination tradition. ${ }^{46}$ In Southeast Asia, the nuns' ordination existed at least until the thirteenth century, but then became extinct, while in Tibet there is no proof that it was ever introduced. Still, more and more women of the Theravāda and Tibetan traditions seek to obtain the full ordination, and several attempts have been carried out, mostly with the help of witnesses of the Dharmaguptaka tradition. Many Buddhist masters, however, oppose

different, prätimokșa text. In order to be a samagra samgha, all participants have to recite the same prātimoksa. For references, see Heirman 2007:193.

45) Song gaoseng zhuan 宋高僧傳, T. 2061:793c26-27. See also Tang 1996, 2:828829; Heirman 2002b:414.

46) Still, an ordination lineage going back to the fifth century C.E. is impossible to verify historically. Interruptions cannot be excluded. (See Li 2000a:107-140 on the revival of dual ordination in Taiwan; see also Li 2000b:198, note 53.) 
these attempts, or hesitate to accept them. ${ }^{47}$ It is important to note that reactions on the full ordination attempts can vary widely from region to region. The context in which Buddhist women organize themselves in nunneries primarily influences their living conditions and the status they can acquire in the surrounding society. On the other hand, growing internationalization of Buddhist communities introduces new ideas into formerly rather independent environments, thus accelerating local debates. The mix of local conditions and internationalization has created new tensions, such as oppositions between western nuns ordained in traditionally Asian traditions and local Asian nuns' communities. It also stimulated differences of opinion between revivalist monks, in favour of the (re-)introduction of the status of fully ordained nuns in traditions in which it is presently not or not fully accepted, and more conservative monks who state that such a (re-)introduction is legally not possible. The new international context also activates the debate on legitimacy, raising questions as to which ordination ceremony can be considered as legally correct. Moreover, it stirs up discussions between fully ordained nuns and other Buddhist female monastics on their respective positions in the Buddhist samgha. ${ }^{48}$

The above discussions take place against the background of the realities of life for women's Buddhist communities in different regions. While in some areas, the communities can support themselves relatively well, in other areas, they are poor with only a very limited access to education. ${ }^{49}$ Undoubtedly, as shown by K. Gutschow (2004), this background greatly influences the tone and the outcome of the debate on revival of a full ordination for nuns. For the present research, a study of the economic or social situation of women's communities would lead us too far afield, but we have to keep in mind that it is especially the more educated women who take part in the debate, and that it is precisely the same women who come into contact with the globalized Buddhist context.

In the following, we will focus on the most recent debates held in an international context, and more particularly on the technical questions

\footnotetext{
47) For details see, among others, Gutschow 2004:168-173; Kawanami 2007:234-236.

48) For an analysis of these tensions, see Cheng 2007:166-76; Kawanami 2007.

49) See, for instance, a study on women's communities in Zangskar by K. Gutschow 2004:77-122.
} 
that arose out of them. How these questions are further interpreted in the many different contexts in which Buddhist women organize their lives has to remain beyond the scope of the present research.

\section{Background}

The most important international attempts to revive a full ordination for women in all Buddhist traditions started about twenty years ago. ${ }^{50}$ Since the beginning of the eighties, nuns of the Tibetan tradition have received the full ordination in Chinese monasteries. In 1988, women from different traditions gathered in Los Angeles to receive the full ordination at the Xilai Temple, a branch of the Taiwanese Foguangshan monastery (Li 2000b:179). ${ }^{51}$ The latter ordination ceremony was the start of other international ordination gatherings conducted by nuns of the Dharmaguptaka tradition. In 1996, an ordination ceremony was held in Sarnath, India, under the guidance of Korean monastics of the Jogye Order. ${ }^{52}$ At that occasion, ten Sinhalese women received for the first time a full bhiksuni $\bar{\imath}$ ordination. ${ }^{53} \mathrm{~A}$ most ambitious gathering was an ordination ceremony held in 1998 in Bodhgaya in India, again conducted by the Foguangshan monastery. The ceremony explicitly aimed at restoring the Tibetan and Theravāda ordination of nuns $(\mathrm{Li}$ 2000b:168-180; Chandler 2004:157-165). With reference to this Bodhgaya ceremony, the Sinhalese Rangiri Dambulu monastery consequently organized several ordination ceremonies. Although the latter monastery does not reject the Bodhgaya ordination, it considers it to be "not Theravāda enough." It therefore decided to re-confer ordination according to the Theravāda procedure to those who became nuns with the help of Dharmaguptaka witnesses (De Silva 2003:129; Kawanami

\footnotetext{
50) These were triggered by the creation of an international Buddhist women's association (Sakyadhita) in 1987 in Bodhgaya, in India (for details, see Mrozik, 2009:360-361).

51) Foguangshan is a Chinese Mahāyāna Buddhist order for monks and nuns founded in 1967 by the monk Xingyun, in Jiangsu in 1927. It has more than one hundred branches all over the world.

52) The Jogye order is a Korean Son (Jap. Zen) Buddhist order for monks and nuns founded in the middle of the fourteenth century.

53) For a brief report by one of the women participants and for an overview of objections raised by Sinhalese monks, see Kusuma Devendra 2007. See also De Silva 2004:126-127.
} 
2007:227/228). Still, opposition to a full ordination for women remains at times fierce and divides the Sinhalese samgha. ${ }^{54}$

The movement for more organizational rights for women and for a full bhiksuni ordination continues to develop further. The latest major event took place in Hamburg in July 2007, at the so-called First International Congress on Buddhist Women's Role in the Sangha, Bhikshuni Vinaya and Ordination Lineages with H. H. the Dalai Lama. As we will see in the last part of the present paper, discussions from the past again play a major role in today's debate.

\section{First International Congress on Buddhist Women's Role in the Sangha}

In July 2007, on the initiative of Western Buddhist women, a large conference on Buddhist nuns was held, with the Dalai Lama present on its last day. ${ }^{55}$ The conference mainly aimed at reviving a Mūlasarvāstivāda full ordination for nuns, although representatives of Theravāda orders were equally invited. The conference differed from the previous events in the sense that the organizers did not carry out any ordinations, but hoped to obtain an approval for a Mūlasarvāstivāda bhikșuñ ordination from the most representative Tibetan master, the Dalai Lama. The international conference brought together representatives from the Dharmaguptaka, Theravāda and Mūlasarvāstivāda traditions, and from many different regions.

As had been the case at earlier events, technical questions played a central role in the debate. One of the major issues was whether a possible (re-)establishment of a full ordination for nuns should be done through a dual ordination - in the presence of an adequate quorum of monks and nuns - or through a single ordination, by monk witnesses only. The advantage of a dual ordination is that it follows the rule of a twofold ordination ceremony (in the nuns' order and in the monks' order) as stipulated by the vinayas. It implies, however, that one has to involve nun witnesses from a tradition (in casu Dharmaguptaka)

54) For more details on the recent revival ordinations, see for the Tibetan tradition Havnevik 1990:44-45, 150, 199-202; Gutschow 2004:169-173. For the Theravāda tradition see Bartholomeusz 1992:46-55; [1994] 1996:165-169, 181-190; Wijayasundara 1999; De Silva 2004:121-134; LeVine and Gellner 2004:178-193; Seeger 2006-2008:155-173; Mrozik 2009:364-369.

55) For a description of the events, see Mrozik 2009:369-372. 
different from the one in which one ordains. ${ }^{56}$ This involvement of Dharmaguptaka nuns can only be avoided if one opts for a single ordination, as has been the case, according to several vinaya traditions, for the Śākya women who followed Mahāprajāpatī in the Buddhist order. On the other hand, a single ordination goes against the rule of a twofold ceremony. ${ }^{57}$

\section{Major Technical Issues}

The technical discussion on the revival of a full ordination for nuns is linked to two major issues: first, how strictly does one have to follow the rules of the vinaya, more particularly of the gurudharmas, and second, to what extent can different vinaya traditions work together? One of the central rules of the gurudharmas stipulates that, after a probationary period of two years, an ordination ceremony has to be carried out first in the nuns' order and then in the monks' order, which implies a legally valid quorum of fully ordained nun and monk witnesses. A dual ordination responds to these demands, but opens a discussion on the validity of the Dharmaguptaka nun witnesses. Not only do they not strictly apply for themselves the rules on the probationary period, but more importantly, they belong to a different vinaya tradition. As we have seen above, in principle vinaya traditions exclude each other, although historic precedents of close collaboration are known - such as the second ordination ceremony for nuns in fifth century China. An additional obstacle, at least for the Theravāda nuns, is that the Dharmaguptaka nuns also follow the Mahāyāna tradition, and thus the bodhisattva vows and bodhisattva ordination are linked to it. The latter ordination is added to the traditional vinaya ordination..$^{58}$ The question

\footnotetext{
56) It is in this context that most recently, at a meeting held in April 2008 at Dharamsala, Tibetan nuns pleaded for a single ordination in the Mūlasarvāstivāda lineage, rather than a dual one in the presence of Dharmaguptaka witnesses. See the newsletter of the Tibetan Nuns Project (www.tnp.org; accessed 11 May 2009), winter 2008:2 and 6 .

57) This discussion is not new. A difficult choice between the two options has been at stake in earlier twentieth century discussions. (See, among others, Li 2000b:182-184; LeVine and Gellner 2004:181-182).

58) From the fifth century on, there was a growing popularity of the so-called bodhisattva rules, often seen as a Mahāyāna supplement to the vinaya rules. In China, this
} 
thus remains whether nuns from one tradition, in casu the Dharmaguptaka tradition now followed by Mahāyāna Buddhists, can legally function as witnesses in a procedure leading to the (re-)introduction of the full ordination for nuns in other traditions, in casu the Theravāda and Tibetan traditions. In the case that the answer is negative, a single ordination seems inevitably to be the only possible way, although it goes against a strict interpretation of the vinaya rules.

At the conference, several proposals were made to overcome the impasse, and again the two main issues were highlighted: the gurudharmas and the legal collaboration of different vinaya traditions. From an academic point of view (supported by many monastics), the vinaya is a compendium of texts that was adapted during many centuries before it became finalized. In this context, it is stated that the concept of the eight gurudharmas was in all likelihood made after the death of the historical Buddha, implying that stipulations such as a probationary period or a twofold ordination were in all probability not there from the start. ${ }^{59}$ Several participants at the conference also pointed out that

lead to the instauration of a second ordination ceremony following shortly after the Dharmaguptaka ordination. This bodhisattva ordination is centered around a fifthcentury text, the Fanwang jing 梵網經 (T. 1484), the Brahmäs Net Sutra. For more details, see among others, Groner 1990. For Theravāda Buddhists, an official Mahāyāna involvement is hard to accept (cf. Bartholomeusz [1994] 1996:147, 181; Harvey 2000:397-398; Cheng 2007:176-185; Kawanami 2007:226-229, 232-234, 237-238; Kusuma 2007; Seeger 2006-2008:162).

59) See, for instance, Shih Heng-ching 2007 and Huimin bhikșu 2007. See also note 8. While a single ordination is most often understood as an ordination by monks only, Jin-il Chung (2006:13-14) has suggested that it is not impossible that, at first, the bhiksunisamgha developed in a way that is parallel to the bhiksusamgha: just like the first monks, the first nuns were ordained through a formula pronounced by the Buddha himself: "ehi bhikșu," "welcome monk" and "ehi bhikșunī," "welcome nun." The nuns' community then developed just as the monks' community did, finally leading to a jüapticaturtha karman ordination ceremony for monks in the bhikșsamgha and for nuns in the bhiksunisamgha. Both communities thus had their own single ordination ceremony executed by their own members. The second ordination ceremony for women in the bhiksusamgha is then only a later addition. The latter hypothesis, if adopted by present-day nuns, would open the possibility of a single ordination by nuns only. It does not change, however, the question on the validity of witnesses of different traditions, given the fact that only Dharmaguptaka nuns would be potential witnesses. 
the validity of witnesses very much depends on the interpretation of the vinaya texts, always keeping in mind that at the time of the Buddha there was no such thing as the distinction among vinaya traditions. ${ }^{60} \mathrm{In}$ this context, the historic precedent of the second ordination of Chinese women is often referenced. As seen above, the witnesses at this second ordination ceremony were probably from a tradition that was different from the one being inaugurated in China. Still, all participants might have recited the same (Chinese) texts, and their validity was not questioned. The precedent potentially opens a discussion on a change of ordination tradition without any ceremony taking place. ${ }^{61}$ If nuns ordained in one tradition just by themselves start to recite the prätimoksa texts of another tradition at the posadha ceremony - as, according to my opinion, is not unlikely to have happened in fifth century China, have they then changed tradition and are they consequently legally valid witnesses in their new tradition? Obviously, the vinayas do not comment on this, since differences between traditions as known in China in the fifth century or as known today, were not yet at stake at the time when the vinaya texts were finalized. However, without the approval of the senior communities of the respective traditions, such a change of ordination is unlikely to be recognized.

For some it seems wiser to avoid any more discussion on the intermingling of different vinaya traditions. In that case, a single ordination (by monks only) would remain the only possible way. Supporters of this solution point out that, although a single ordination goes against the vinaya stipulations, some earlier vinaya masters and even some vinaya passages, state that participating monks in fact only commit a very small offense. So, why not commit such an offense for the sake of the revival of a nuns' ordination? ${ }^{62}$

60) See, for instance, Hartmann 2007 and Shih Heng-ching 2007. See also Seeger 2006-2008:162-163.

61) See, for instance, Shih Heng-ching 2007.

62) Clarke 2007 (Mūlasarvāstivāda); Shih Heng-ching 2007 (Dharmaguptaka). The opinion that a single ordination by monks is valid, even though in senso strictu an offense has been committed, is already expressed in the fifth century by the monk Gunavarman when he is asked questions about the validity of the Chinese nuns' order (Gaoseng zhuan, T. 2059:341a28-b7, translation Shih 1968:132; and Biqiuni zhuan, T. 2063:937b24-c3, translation Tsai 1994:36-37). Gunavarman's opinion is repeated by the vinaya master Daoxuan (596-667) in his commentary Sifen lü shanfan buque 


\section{Philological Research}

As seen above, the debates, in the present as well as in the past, often involve arguments of a strict interpretation of the vinaya as well as arguments of a more pragmatic attitude based on the intention of the vinaya rules rather than on the letter. Added to this is the present-day common reference to philological research on vinaya texts, in which all parties hope to find their point of view confirmed. Traditionalists refer to the strict interpretation of the gurudharmas, revivalists to the evolution still visible in the vinaya texts. Others hope to find a clue, small as it might be, to revive a nuns' ordination without going against the strict interpretation of the vinaya rules. ${ }^{63}$ In this context, it should be observed that viewpoints based both on academic research and on religious belief could "eventually lead to a futile dispute between positions marked by either belief or rationality," as pointed out by J.-U. Hartmann (2007). A good example of this is the discussion on the role played by the Buddha himself in the ordination of the first nun Mahāprajāpatī. According to tradition, as we have seen above, the Buddha himself allowed women to enter the Buddhist monastic order, and gave them the eight gurudharmas. In a recent research, O. von Hinüber has challenged the latter tradition (von Hinüber 2008). Mainly based on the fact that in the Pali texts of the Theravāda tradition the Buddha is never directly involved in any ordination of a nun, and that he is never mentioned as talking to a nun in the texts of the Suttapitaka, ${ }^{64}$ von Hinüber concludes that the Buddha himself never explicitly allowed women in the order, but that instead nunneries came into being (shortly) after the demise of the Buddha. Given the fact that many researchers have already pointed out that the concept of the eight gurudharmas is in all probability a late construction of vinaya redactors, the idea is maybe not that

xingshi chao 四分律刪繁補關行事鈔, An Abridged and Explanatory Commentary on the Dharmaguptakavinaya (T. 1804:p.51c9-15). See also Huimin 2007.

63) This was also the wish expressed by the Dalai Lama in his concluding speech of the Hamburg conference (cf. life recording DVD 20 July, 1.30-4.00 PM, 2007, Mülheim, Auditorium Netzwerk).

64) The Suttapitaka, Basket of the Teaching, is a collection of very early Buddhist texts, mainly comprising the discourses of the Buddha and his discussions with Buddhists and non-Buddhists. (For details, see von Hinüber 1996:23-64.) 
revolutionary. ${ }^{65}$ If accepted, it implies that the first women were ordained by monks only, and that monks could do so also today. It is clear that for the bhiksunisamgha this idea is not at all attractive. The procedure does not link the bhiksunisamgha to the historical Buddha, and therefore greatly reduces its status. Even worse, it potentially impugns the foundations of the nunneries, which are based on an uninterrupted transmission of ordinations since the time of the Buddha.

Apart from these considerations, it also remains very unsure whether a coming into being of the nuns' community after the demise of the Buddha can be verified beyond any doubt. On the contrary, as discussed at length by bhikkhu Anālayo, several arguments can as well be taken as pointing to the authenticity of the account of the nuns' order being started by the Buddha himself (Anālayo 2008:110-126). The use of a particular terminology for the ordination of nuns, as observed in the Pâli Vinaya, might indicate, for instance, that the events were recorded without giving in to any tendency of uniformity, thus suggesting at least that the story was authentic and not copied from available data on the monks' ordination. While the Buddha is not said to have interacted with individual nuns, several passages in the Păli canon (and even more in other canons, in which the Buddha also directly addresses nuns) discuss meetings with a group of nuns, or mention reports about nuns being given to the Buddha, suggesting that he was still alive when the order of nuns was already rather active.

Philological research might never entirely retrace the events of the Buddha's life, certainly not when the concept of a "multiplicity of voices" found in the Buddhist texts is emphasized. ${ }^{66}$ It shows that texts might vary and that compilers and transmitters of texts might have their own reasons to preserve or alter an account. In this sense, looking for the religious truth through an academic process might indeed be - to use Hartmann's word - a "futile" exercise.

65) The question of the role played by the Buddha in the construction of the eight gurudharmas has been raised before by, for instance, Chung 2006:13 note 90. Given the fact that the concept of the eight gurudharmas is in all probability a relatively late addition, one can indeed ask the question whether this addition was made during the lifetime of the historical Buddha, and if so, whether it was in his presence.

66) Cf. Sponberg 1992:3; Anālayo 2008:126. 


\section{The Dalai Lama's Response}

Greatly anticipated of course was the viewpoint of the Dalai Lama, seen by the organizers of the conference as authoritative for the re-establishment of a full ordination for nuns within the Mūlasarvāstivāda tradition. His reply was twofold. ${ }^{67}$ First, he stated that if he were Buddha, he would certainly allow women to become fully ordained. This not being the case, he can only rely on the vinaya, and for now he does not see the possibility to legally reinstate the full Mūlasarvāstivāda ordination. Second, he allows nuns ordained in the Dharmaguptaka tradition to hold three key ceremonies in Tibetan, using a Tibetan translation of the Chinese Dharmaguptaka ceremonial texts. HIs permission concerns the procedures of varșa, posadha, and praväran $\bar{a}^{68}$ The Dalai Lama's statements are related to two essential issues. The first one is the conviction that Mahāprajāpatî’s ordination, as well as the ordination of the Saakya women who accompanied her, cannot be seen as a precedent. They are exceptional cases, after which only a ceremony based on a jnapticaturtha karman, in the presence of the necessary quorum of witnesses can be legally accepted. The second issue is related to the idea that vinayas mutually exclude each other. As seen above, legal procedures have to be carried out by a samagra samgha, implying unity in the recitation of the prātimokșa at the posadha ceremony. Members belonging to different vinaya traditions consequently cannot hold the posadha ceremony together, and by extension they also cannot conduct the pravārana ceremony, which is equally based on the precepts of the

67) Cf. live recording DVD 20 July, 1.30-4.00 PM, 2007, Mülheim, Auditorium Netzwerk.

68) At the very beginning, Buddhist monastics all were wandering ascetics. They only had a permanent residence during the rainy season (varsa), which lasts three months. The entrance into residence takes place through pronouncing a declaration in the presence of the other monastics (Dharmaguptakavinaya, T. 1428:830c7-11). The posadha ceremony is a ceremony held every fortnight. At that occasion, the prätimokș (list of precepts) is recited (see also note 44). For a study of the Mūlasarvāstivāda poṣadha ceremony, see Hu-von Hinüber 1994. The pravāraṇā ceremony (invitation ceremony) is held at the end of the rainy season. At this ceremony every nun invites her fellow nuns and then, in second instance, the monks' order to point out her wrongs, whether seen, heard or suspected. On this ceremony, see a study by J. Chung 1998. For summaries and references to the chapters of varsa, posadha, and pravārañā in all vinaya traditions, see Frauwallner 1956:78-88. 
prätimoksa and which at the end of the rainy season often replaces the regular posadha ceremony. ${ }^{69}$

Reciting the Dharmaguptaka procedures in Tibetan, on the one hand brings the Dharmaguptaka ceremonies (including a higher ordination) closer to a Tibetan-speaking community, but on the other hand draws a clear line between the (Tibetan) Mūlasarvāstivāda tradition and the Dharmaguptaka tradition. It does not allow women to enter the Mūlasarvāstivāda monastic organization, but sets them apart. It can therefore be doubted whether this proposal is acceptable to the Buddhist women who plead for an institutionally equal position within the Mūlasarvāstivāda tradition.

\section{Conclusion}

The debates of the twentieth and twenty-first century on the validity and (re-)establishment of a full ordination for nuns are being constantly fuelled by vinaya issues, linked to historic precedents, and transferred to a present-day context. The debates take place on local levels as well as in an international context. They mostly go back to Mahāprajāpatī and her acceptance of the eight fundamental rules, which impose an ordination ceremony in the presence of fully ordained nun and monk witnesses. This was the case when the bhiksuni $\bar{\imath}$ ordination was introduced in Sri Lanka, and it constituted the heart of the debate when Chinese nuns questioned the validity of their ordination in the middle of the fifth century and asked for a second ordination in the presence of legally valid witnesses. This second ordination ceremony was also meant to link the Chinese ordination tradition to the time of the Buddha and of the first Buddhist nuns. The same issue of witnesses is again at stake in today's discussion regarding a single or dual ordination. One element has been added though, namely the differences between the traditions, and especially between the Theravāda and Mahāyāna orders, which leads to discussions on their possible or impossible legal collaboration.

At the latest international event in Hamburg, many strove to find a legal vinaya way to re-establish the nuns' ordination, especially in the Tibetan lineage, relying on a philological scrutiny of vinaya passages.

69) For details, see Chung 1998:40-52. 
While from a religious point of view, all vinaya texts, including the eight fundamental rules, are linked to the personal views of the Buddha, from an academic point of view, the vinaya texts are seen as a body of texts that were constantly adapted until at a certain point the vinayas became finalized. But even then Buddhist masters continued to comment upon these texts, often pleading for pragmatic solutions in their given contexts. ${ }^{70}$ Apart from the question of how far a debate that mixes religious and scientific aims is methodologically correct, it can be doubted whether this procedure will ever lead to legally acceptable results for the Buddhist communities. Putting the methodological questions aside, it is clear that many present-day discussions focus either on the intention of the vinaya or on a strict technical interpretation. The outcome of the debates will inevitably be linked to the degree of acceptance by the established orders in the various regions of the world. Without the support of the senior monks, including the Dalai Lama, recognition will remain difficult.

\section{Abbreviations}

T. Taishō Shinshū Daizōkyō 大正新修大藏 經, J. Takakusu, K. Watanabe (eds.). Tokyo, 1924-1935.

Vin The Vinaya Pitakam, H. Oldenberg (ed.). London: Pali Text Society. Volume I [1879] 1964; Volume II [1880] 1964.

\section{Other References}

Anālayo. 2008. "Theories on the Foundation of the Nuns' Order - A Critical Evaluation." Journal of the Centre for Buddhist Studies Sri Lanka VI:105-142.

Anon. 2007. First International Congress on Buddhist Women's Role in the Sangha, Bhikshuni Vinaya and Ordination Lineages with H.H. the Dalai Lama, book of papers, unnumbered pages.

Bartholomeusz, Tessa. 1992. “The Female Mendicant in Buddhist Srī Lañkā.” In José I. Cabezón (ed.), Buddhism, Sexuality and Gender, Delhi: Sri Satguru Publications, 37-61.

70) On several attitudes of early Chinese masters towards vinaya rules, see Heirman 2008b. 
. [1994] 1996. Women under the Bō Tree, Buddhist Nuns in Sri Lanka. Cambridge: Cambridge University Press.

Bechert, Heinz. 1961. "Aśokas 'Schismenedikt' und der Begriff Sanghabheda.” Wiener Zeitschrift für die Kunde Süd- und Ostasiens 5:18-52.

1982. "The Importance of Aśoka's So-called Schism Edict." In Louise A. Hercus, Jacobus F.B. Kuiper, Tissa Rajapatirana and Edmund R. Skrzypczak (eds.), Indological and Buddhist Studies, Volume in Honour of Professor J.W. de Jong on his Sixtieth Birthday, Canberra: Faculty of Asian Studies, 61-68.

—. 1993. "On the Origination and Characteristics of Buddhist Nikāyas, or Schools.” In Premier Colloque Etienne Lamotte. Louvain-la-Neuve: Institut Orientaliste de Louvain, 51-56.

Bingenheimer, Marcus. 2004. Der Mönchsgelehrte Yinshun (1906*) und seine Bedeutung für den Chinesisch-Taiwanischen Buddhismus des 20. Jahrhunderts. Ph.D. Julius-Maximilians-Universität Würzburg.

Chandler, Stuart. 2004. Establishing a Pure Land on Earth: the Foguang Buddhist Perspective on Modernization and Globalization. Honololu: University of Hawai' $\mathrm{i}$ Press.

Cheng, Wei-yi. 2007. Buddhist Nuns in Taiwan and Sri Lanka, A Critique of the Feminist Perspective. London: Routledge.

Chung, Jin-il. 1998. Die Pravārañā in den kanonischen Vinaya-Texten der Mülasarvāstivādin und der Sarvāstivādin. Göttingen: Vandenhoeck \& Ruprecht.

—. 2006. "Ursprung und Wandel der Aufnahme von Frauen in den buddhistischen Orden nach der kanonischen Überlieferung — eine Randbemerkung." Annual of the Sanko Research Institute for the Studies of Buddhism 37:1-16.

Clarke, Shayne. 2007. "Creating Nuns out of Thin Air: Problems and Possible Solutions concerning the Ordination of Nuns according to the Tibetan Monastic Code." In First International Congress on Buddhist Women's Role in the Sangha, Bhikshuni Vinaya and Ordination Lineages with H.H. the Dalai Lama, book of papers, unnumbered pages.

De Rauw, Tom. 2005. "Baochang: Sixh-Century Biographer of Buddhist Monks... and Nuns?" Journal of the American Oriental Society 125(2):203-218.

De Silva, Ranjani. 2004. "Reclaiming the Robe: Reviving the Bhikkhuni Order in Sri Lanka.” In Karma Lekshe Tsomo (ed.), Buddhist Women and Social Justice, New York: State University of New York Press, 119-135.

Frauwallner, Erich. 1956. The Earliest Vinaya and the Beginnings of Buddhist Literature. Roma: Istituto Italiano per il Medio ed Estremo Oriente.

Geiger, Wilhelm. 1912. The Mahāvamsa or the Great Chronicle of Ceylon. London: Pali Text Society, Luzac \& Company.

, ed. 1958. The Mahãvamsa. London: Pali Text Society, Luzac \& Company.

Georgieva, Valentina. 2000. Buddhist Nuns in China, from the Six Dynasties to the Tang. Doctoral dissertation, Leiden University.

Groner, Paul. 1990. "The Ordination Ritual in the Platform Sutra within the Context of East Asian Buddhist Vinaya Tradition." In Fo Kuang Shan Report of International Conference on Ch'an Buddhism, Kaohsiung: Fo-kuang shan, 220-250. 
Gunawardana, Ranaweera A.L.H. 1988. "Subtile Silks of Ferreous Firmness, Buddhist Nuns in Ancient and Early Medieval Sri Lanka and their Role in the Propagation of Buddhism." The Sri Lanka Journal of the Humanities 14:1-59.

Gutschow, Kim. 2000. "Novice Ordination for Women: the Rhetoric and Reality of Female Monasticism in Northwest India.” In Ellison B. Findly (ed.), Women's Buddhism, Buddhism's Women. Tradition, Revision, Renewal, Boston: Wisdom Publications, 103-118.

- 2004. Being a Buddhist Nun, The Struggle for Enlightenment in the Himalayas. Cambridge, Massachusetts: Harvard University Press.

Hartmann, Jens-Uwe. 2007. "The Vinaya between History and Modernity: Some General Reflections." In First International Congress on Buddhist Women's Role in the Sangha, Bhikshuni Vinaya and Ordination Lineages with H.H. the Dalai Lama, book of papers, unnumbered pages.

Harvey, Peter. 1990. An Introduction to Buddhism, Teaching, History and Practices. Cambridge: Cambridge University Press.

- 2000. An Introduction to Buddhist Ethics. Cambridge: Cambridge University Press.

Harvey, Peter, ed. 2001. Buddhism. London: Continuüm.

Havnevik, Hanna. 1990. Tibetan Buddhist Nuns. Oslo: Norwegian University Press.

Heirman, Ann. 1997. "Some Remarks on the Rise of the Bhiksunisamgha and on the Ordination Ceremony for Bhiksunīs according to the Dharmaguptaka Vinaya." Journal of the International Association of Buddhist Studies 20(2):33-85.

1998. "Gurudharma: an Important Vinaya Rule." Indian Journal of Buddhist Studies 10(1-2):18-26.

- 1999. "Vinaya: Perpetuum Mobile." Asiatische Studien/Études Asiatiques LIII(4):849-871.

- 2001. "Chinese Nuns and their Ordination in Fifth Century China." Journal of the International Association of Chinese Studies 24(2):275-304.

- 2002a. 'The Discipline in Four Parts', Rules for Nuns according to the Dharmaguptakavinaya. Delhi: Motilal Banarsidass, 3 Parts.

- 2002b. "Can we trace the Early Dharmaguptakas?" T'oung Pao 88:396-429.

- 2007. "Vinaya from India to China". In Ann Heirman and Stephan-Peter Bumbacher (eds.), The Spread of Buddhism, Leiden: Brill, 167-202.

- 2008a. "Where is the Probationer in the Chinese Buddhist Monasteries?"

Zeitschrift der Deutschen Morgenländischen Gesellschaft 158(1):105-137.

_. 2008b. "Indian Disciplinary Rules and their Early Chinese Adepts: A Buddhist Reality." Journal of the American Oriental Society 128(2):257-272.

_. "Fifth Century Chinese Nuns: An Exemplary Case." Buddhist Studies Review 27 (1):61-76.

von Hinüber, Oskar. 1996. A Handbook of Pali Literature. Berlin: Walter de Gruyter. - 1999. Das Pātimokkhasutta der Theravadin, Studien zur Literatur des Theraväda-Buddhismus II. Stuttgart: Franz Steiner Verlag.

- 2008. "The Foundation of the Bhikkhunisamgha, A Contribution to the Earliest History of Buddhism." Annual Report of The International Research Institute for Advanced Buddhology at Soka University for the Academic Year 2007, XI:3-29. 
Horner, Isaline B. 1930. Women under Primitive Buddhism, Laywomen and Almswomen. New York: E.P. Dutton and Company.

Hu-von Hinüber, Haiyan. 1994. Das Poșadhavastu, Vorschriften für die buddhistsiche Beichtfeier im Vinaya der Mülasarvāstivādins. Reinbek: Dr. Inge Wezler Verlag für Orientalische Fachpublikationen.

Huimin. 2007. "An Inquiry Concerning the Lineage of Bhiksuñi Ordination.” In First International Congress on Buddhist Women's Role in the Sangha, Bhikshuni Vinaya and Ordination Lineages with H.H. the Dalai Lama, book of papers, unnumbered pages.

Hüsken, Ute. 1993. "Die Legende von der Einrichtung des buddhistischen Nonnenordens im Vinaya-Pitaka der Theravādin.” In Reinhold Grünendahl, JensUwe Hartmann and Petra Kieffer-Pülz (eds.), Studien zur Indologie und Buddhismuskunde, Festgabe des Seminars für Indologie und Buddhismuskunde für Professor Dr. Heinz Bechert zum 60. Geburtstag am 26. Juni 1992, Bonn: Indica et Tibetica Verlag, 151-170.

- 1997. Die Vorschriften für die buddhistische Nonnengemeinde im Vinaya-Pitaka der Theravädin. Berlin: Dietrich Reimer Verlag.

Kawanami, Hiroko. 1990. "The Religious Standing of Burmese Buddhist Nuns (thilashin): The Ten Precepts and Religious Respect Words." The Journal of the International Association of Buddhist Studies 13(1):17-39.

- 2007. "The Bhikkhunī Ordination Debate: Global Aspirations, Local Concerns, with special emphasis on the views of the monastic community in Burma." Buddhist Studies Review 24(2):226-244.

Kieffer-Pülz, Petra. 1992. Die Sìmā, Vorschriften zur Regelung der buddhistischen Gemeindegrenze in älteren buddhistischen Texten. Berlin: Dieter Reimer Verlag.

2005. "Ehe- oder Lebensjahre? Die Altersangabe für eine "verheiratete" Frau (gihigatā) in den Rechtstexten der Theravādin." Zeitschrift der Deutschen Morgenländischen Gesellschaft 155(1):199-238.

Kusuma Devendra. 2007. “Theravada Bhikkhunis.” In First International Congress on Buddhist Women's Role in the Sangha, Bhikshuni Vinaya and Ordination Lineages with H.H. the Dalai Lama, book of papers, unnumbered pages.

LeVine, Sarah and David Gellner. 2004. Rebuilding Buddhism, The Theravada Movement in Twentieth-Century Nepal. Cambridge, Massachusetts: Harvard University Press.

Li, Yu-chen. 2000a. Crafting Women's Religious Experience in a Patrilineal Society: Taiwanese Buddhist Nuns in Action (1945-1999). Ph.D. Cornell University.

- 2000b. "Ordination, Legitimacy, and Sisterhood, The International Full Ordination Ceremony in Bodhgaya." In Innovative Buddhist Women, Swimming against the Stream, ed. Karma Lekshe Tsomo, Richmond: Curzon Press, $168-198$.

Meeks, Lori. 2006. "Reconfiguring Ritual Authenticity, The Ordinations Traditions of Aristicratic Women in Premodern Japan.” Japanese Journal of Religious Studies 33(1):51-71.

Mrozik, Susanne. 2009. "A Robed Revolution: The Contemporary Buddhist Nun's (Bhikșunī) Movement." Religion Compass 3(3):360-378. 
Nolot, Edith. 1991. Règles de discipline des nonnes bouddhistes, le bhikșnīvinaya de l'école Mahāsāmghika-Lokottaravādin. Paris: Collège de France.

Ohnuma, Reiko. 2006. "Debt to the Mother: A Neglected Aspect of the Founding of the Buddhist Nuns' Order." Journal of the American Academy of Religion 74(4):861-901.

Oldenberg, Hermann 1879. The Dipavamsa: An Ancient Buddhist Historical Record. London: Williams and Norgate.

Roth, Gustav. 1970. Bhikșuni-Vinaya, Including Bhikșnī-Prakirnaka and a Summary of the Bhikșu-Prakìrnaka of the Ärya-Mahāsämghika-Lokottaravādin. Patna: Kashi Prasad Jayaswal Research Institute.

Salgado, Nirmala. 2004. "Religious Identities of Buddhist Nuns: Training Precepts, Renunciant Attire, and Nomenclature in Theravāda Buddhism." Journal of the American Academy of Religion 72(4):935-953.

Schopen, Gregory. 1997. Bones, Stones, and Buddhist Monks. Collected Papers on the Archaeology, Epigraphy, and Texts of Monastic Buddhism in India. Honolulu: University of Hawai'i Press.

- 2004. Buddhist Monks and Business Matters. Still More Papers on Monastic Buddhism in India. Honolulu: University of Hawai'i Press.

Schmidt, Michael. 1993. "Bhikṣuṇi-Karmavācanā, Die Handschrift Sansk. c25(R) der Bodleian Library Oxford.” In Reinhold Grünendahl, Jens-Uwe Hartmann and Petra Kieffer-Pülz (eds.), Studien zur Indologie und Buddhismuskunde für Professor Dr. Heinz Bechert zum 60. Geburtstag am 26. Juni 1992, Bonn: Indica et Tibetica, 239-288.

Seeger, Martin. 2006-2008. "The Bhikkhuni-Ordination Controversy in Thailand." Journal of the International Association of Buddhist Studies 29(1):155-183.

Shih, Chao-hui 釋昭慧. 2000. “有關受具前階規定之種種一沙彌 (尼), 式叉摩那與「異學四月共住」規定之研究” (“On the regulations on the period before the full ordination: a study on the regulations regarding novices, probationers and women of other doctrines who have to train for four months'). 法光學 壇 4:19-39.

Shih, Heng-ching. 2007. "Three Options: Re-establishing the Bhiksuni Lineage in the Tibetan Tradition." In First International Congress on Buddhist Women's Role in the Sangha, Bhikshuni Vinaya and Ordination Lineages with H.H. the Dalai Lama, book of papers, unnumbered pages.

Shih, Robert. 1968. Biographies des moines éminents (Kao Seng Tchouan) de HoueiKiao, Première Partie: Biographies des premiers traducteurs. Louvain: Institut Orientaliste.

Sponberg, Allan. 1992. "Attitudes toward Women and the Feminine in Early Buddhism." In Buddhism, Sexuality, and Gender, ed. José I. Cabezón, Albany: State University of New York Press, 3-36.

Tang, Yongtong. [1938] 1996. Han Wei Liang-Jin Nanbeichao Fojiaoshi 漢魏兩晉南 北朝佛教史 (History of Buddhism of the Han Wei Liang-Jin Nanbeichao Period). Banqiao: Luotuo Chubanshe, 2 vols. 
Tsai, Kathryn A. 1994. Lives of the Nuns, Biographies of Chinese Buddhist Nuns from the Fourth to the Sixth Centuries. Honolulu, University of Hawai'i Press.

Wijayasundara, Senarat. 1999. "Restoring the Order of Nuns to the Theravādin Tradition.” In Buddhist Women across Cultures: Realizations, ed. Karma Lekshe Tsomo, New York: State University of New York Press, 79-87.

Williams, Liz. 2000. "A Whisper in the Silence: Nuns before Mahāpajāpatî?” Buddhist Studies Review 17(2):167-173.

Wilson, Liz. (1996), Charming Cadavers, Horrific Figurations of the Feminine in Indian Buddhist Hagiographic Literature. Chicago: University of Chicago Press.

Wright, Arthur. 1954. "Biography and Hagiography, Hui-chiao's Lives of Eminent Monks." In Silver Jubilee Volume of Zinbun-Kagaku-Kenkyusyo, Kyoto: Kyoto University, 383-432.

Yuyama, Akira. 1979. Systematische Übersicht über die buddhistische Sanskrit-Literaturl A Systematic Survey of Buddhist Sanskrit Literature. Erster Teil: Vinaya-Text. Wiesbaden: Franz Steiner Verlag. 